\title{
Symptoms and Treatment of Manganese Deficiency in Cycas revoluta Thunb.
}

\author{
Bijan Dehgan', Joseph E. Durando, and Thomas H. Yeager \\ Department of Environmental Horticulture, University of Florida, Gainesville, \\ FL 32611 \\ Additional index words. chelated manganese, chlorosis, necrosis, dieback, deficiency \\ symptoms, sago palm, cycads
}

\begin{abstract}
Cycas revoluta, an important ornamental palm-like plant of warmer regions of the world, often exhibits a foliar chlorotic/necrotic dieback in landscapes. Despite a weak correlation $\left(r^{2} \leq 0.28\right)$ of percent symptoms with soil nutrient levels or $\mathrm{pH}$, symptom severity was correlated more notably $\left(r^{2}=0.49\right)$ with $M n$ and had even a higher correlation $\left(r^{2}=0.61\right)$ with the $\mathrm{Fe}: \mathrm{Mn}$ ratio. Anatomical examination of chlorotic leaflets indicated an accumulation of tanniniferous cells but did not provide direct evidence of Mn deficiency. Although field surveys indicated a link between low Mn levels and Fe : Mn ratio in the plant and appearance of the disorder, the manifestation of symptoms could not be directly correlated with any edaphic factors. However, identical symptoms were induced in young plants by withholding $\mathrm{Mn}$ in a solution culture experiment. Application of chelated Mn on expanding leaves alleviated the disorder, but only for the current growth flush. Irrigation frequency in concert with other cultural practices probably are more responsible for development of symptoms than actual soil Mn inadequacy. In consideration of acute susceptibility of cycads to micronutrient deficiencies, plants should be supplied with a complete micronutrient fertilizer during growth in containers and before field planting.
\end{abstract}

Cycas revoluta, the king sago palm, a nativeof the southern Japanese island of Ryukyu, has been a prized landscape plant in warmer regions of the world for centuries. Although often used in interior landscapes in the United States, its outdoor use is restricted primarily to Florida, Louisiana, Texas, California, and Hawaii. Sago palm leaves are occasionally observed with various degrees of chlorosis and necrosis. The affliction is manifest initially as pale-green areas in developing leaflets in the rachis midsection soon after maturity. As symptoms progress, bright chlorotic spots also develop along the leaflet mm-gins. These are often accompanied by an overall light chlorosis, chlorotic tips, or both. The chlorotic/necrotic areas eventually coalesce in the leaflet middle and result in death of tissue in the afflicted areas. Thes symptom progresses basipetally and acropetally along the rachis and may eventually result in death of all leaves though usually not the caudex. In severe cases,

\footnotetext{
Received for publication 15 July 1993. Accepted for publication 11 Jan. 1994, Journal article no. R-02989 of the Agricultural Experiment Station, Univ. of Florida, Insitute of Food and Agricultural Sciences. Mention of a trademark, proprietary product, or vendor does not constitute a guarantee or warranty of the product, nor does it imply approval or disapproval to the exclusion of other products or vendors that may also be suitable. We thank Albert Dudeck for help with the statistical analyses and Fé Almira and Bart Schutzman for technical assistance. The cost of publishing this paper was defrayed in part by the payment of page charges. Under postal regulations, this paper therefore must be hereby marked advertisement solely to indicate this fact.

'To whom reprint requests should be addressed.
}

the current year's fronds may die during or soon after expansion. Symptoms develop quickly on otherwise healthy plants. In older clumping plants, some members of the clump may exhibit symptoms while others do not. Further, some plants growing in close proximity to others may show severe symptoms while others within the group are healthy. These symptoms are similar to those described for $\mathrm{Mn}$ and $\mathrm{Zn}$ deficiencies in several taxa by Dickey(1977)andinmango (Mangfera indica L.) by Agarwala et al. (1988).

Although a serious problem in many warmer climates, the problem has rarely been mentioned in the literature and, to our knowledge, never methodically studied. Weber (1944) discussed a "blight" of $C$. revoluta but provided no answer to the causative agent. Manganese deficiency has been mentioned as a "suspected cause" by Dickey (1977) based on similarity of the symptoms to that of "frizzle-leaf' or"curly-top" of some true palms. The chlorosis of the cycad, sago palm, however, has been recorded throughout Florida by the Pathology Division of the Florida Dept. of Plant Industry. Thus, the three objectives of this research were: 1) to determine if appearance of the disorder is actually correlated with Mn deficiency; 2) to determine whether Mn deficiency in the plant is the result of low levels of $\mathrm{Mn}$ in the soil; and 3) to explore the possibility of correcting the disorder.

\section{Materials and Methods}

Extent of problem. To determine the incidence and frequency of the problem, in Spring 1985, 27 plants of C. revoluta, in the urban area of Gainesville, Fla., known from previous observations to have synchronous spring growth flush and to exhibit a range of symptoms, were visually rated as to the severity of yellow or necrotic leaflet spots: $<10 \%, 10 \%$ to $49 \%, 50 \%$ to $75 \%$, and $>75 \%$ of the leaflets affected. Leaflet samples for anatomical studies were collected from these plants; fixed in FAA; and, following standard methods (Johansen, 1940), embedded in paraffin and longitudinally sectioned at $10 \mu \mathrm{m}$ in thickness with a sliding microtome and stained with safranin and fast green (both Sigma Chemical Co., St. Louis). The sections were mounted on slides and observed with a Nikon AFX-11 microscope.

Mineral concentration. Leaflet tissue exhibiting the problem was removed from each plant, oven-dried at $60 \mathrm{C}$ for $96 \mathrm{~h}$, and ground in a Wiley mill with a 0.425 -mm-diameter pore screen $(=40 \mathrm{mesh})$. Ashed $600-\mathrm{mg}$ samples were digested in concentrated $\mathrm{HC} 1$, evaporated to dryness, and dissolved in six drops of concentrated $\mathrm{HC} 1$; the total volume was brought to $30 \mathrm{ml}$ for a final 1:50 dilution factor. The filtered solution was then submitted to the Institute of Food and Agricultural Sciences (IFAS) Extension Soil Testing and Analytical Research Laboratory. Potassium, $\mathrm{Mn}, \mathrm{Fe}, \mathrm{Zn}, \mathrm{Ca}, \mathrm{Mg}, \mathrm{Cu}$, and $\mathrm{Al}$ concentrations were determined by atomic absorption spectrophotometry and $\mathrm{P}$ by the ammonium molybdate/ascorbic acid calorimetric method of Donohue(1983).

A 25-cm-deep core soil sample was taken from three points around each specimen at 30 $\mathrm{cm}$ from the plant. These three samples were combined, oven-dried, ground, and passed through a 10 -mesh $(2.0 \mathrm{~mm})$ screen. A $25-\mathrm{ml}$ portion was removed from each sample and mixed with $50 \mathrm{ml}$ of deionized water for $\mathrm{pH}$ determination. The $\mathrm{pH}$ of the slurry was measured with a $\mathrm{pH} /$ ion meter (Accumet, model 230A; Fisher Scientific, Orlando, Fla.) after incubation at room temperature for $0.5 \mathrm{~h}$ and again after $36 \mathrm{~h}$. Samples of $5 \mathrm{~g}$ were agitated with $20 \mathrm{ml}$ Mehlich 1 Extractant $(0.05 \mathrm{~N} \mathrm{HC} 1$ in $0.025 \mathrm{~N} \mathrm{H}_{2} \mathrm{SO}_{4}$ ) for $5 \mathrm{~min}$ and filtered. Calcium, $\mathrm{Mg}, \mathrm{K}, \mathrm{Zn}, \mathrm{Mn}, \mathrm{Cu}, \mathrm{Al}, \mathrm{Fe}$, and $\mathrm{Na}$ concentrations of these samples were determined according to the standard procedure of the Florida Extension Soil Testing and Analytical Research Laboratory.

Tissue and soil data were statistically analyzed using regression analysis, with percent symptoms as the dependent variable. Due to theimportanceofFe-Mnrelationships (Somers and Shive, 1942), the ratios of these two nutrients to each other in both the plant and the soil were examined.

Manganese effect. To determine whether manifestation of symptoms was actually the result of Mn deficiency, in Mar. 1986, 36 one-year-old $C$. revoluta seedlings were transplanted into 3.8-liter pots and placed in a greenhouse. All original medium was washed away from the roots, and the seedlings were transplanted into washed $100 \%$ silica sand. Nine blocks of four treatments were arranged in a completely randomized block design, with one plant per experimental unit. The 
treatments included Hoagland Solution 2 (Hoagland and Amen, 1950) modified with 0, $0.25,0.5$, and $\left.1.0 \mathrm{ppm} \mathrm{Mn} \mathrm{(as} \mathrm{MnCl}_{2} \cdot 4 \mathrm{H}_{2} \mathrm{O}\right)$. Each plant was irrigated once every 3 days with 1 liter of solution. All plants were flushed with deionized water weekly to prevent accumulation of salts. Because $C$. revoluta typically produces only one growth flush annually, the experiment was continued until May 1987. Two sets of leaves were harvested for tissue analysis: the first from the growth flush 2 months after initiation of the experiment and the second at the end of the experiment from the most recent growth flush. All leaflets from an entire leaf were used for analysis, as described above.

Prophylaxis. The final phase of the project involved examining an Mn chelate available commercially to prevent deficiencys symptoms. Ten plants with equally discernible symptoms in a variety of landscape situations were selected for treatment. Their routine cultural conditions were not altered. Two sets of five plants each were treated according to manufacturer's recommendations (Stroller Chemical Co. of Florida, Quincy, Fla.): with $30 \mathrm{ml}$ of $35.6 \% \mathrm{Mn}$ salts of phenolic acid solution, plus $20 \mathrm{ml}$ of surfactant (Tween 20), plus $19 \mathrm{mg}$ urea, all in 3.8 liters of water. A control sohttion consisted of all but the Mn. The plants were sprayed early in the morning, when the relative humidity was high and evaporation rate minimal. Treatments were carried out four times at 10-day intervals, from 20 Apr. to 28 May 1987. This interval coincided with the period from emergence to soft but fully expanded new leaves. Because the abaxial leaf surface is thickly covered with pubescence at this time, care was taken to assure thorough coverage of both sides of the leaves. Leaflet samples for tissue analysis were taken in July 1987 from the leaves of the previous year's growth flush before treatment and from the mature leaves of the treated growth flush. Development of the symptoms was monitored throughout the growing season.

\section{Results and Discussion}

Extent of problem. Anatomical features were not indicative of any particular causative agent. None of the symptoms of Mn deficiency mentioned by Bussler ( 1958) were observed, nor did sections of healthy tissue from afflicted plants reveal anatomical evidence of the disorder. Weiland et al. (1975) found the same to be true for Mn-deficient soybeans [Glycine $\max (\mathrm{L}$.) Merrill]. Sections from tissue beginning to exhibit external symptoms revealed an accumulation of tanniniferous cells in the areas of the midvein and abaxial epidermis. As the symptoms became more pronounced, tanniniferous cells also accumulated in the adaxial epidermis and accessory transfusion tissue (not shown). The accumulation of tannins is probably a general stress reaction. Because Mn has no structural role (Weiland et al., 1975), the development of lacunae is probably the result of secondarily induced tissue breakdown.

Mineral concentrations. The results of the

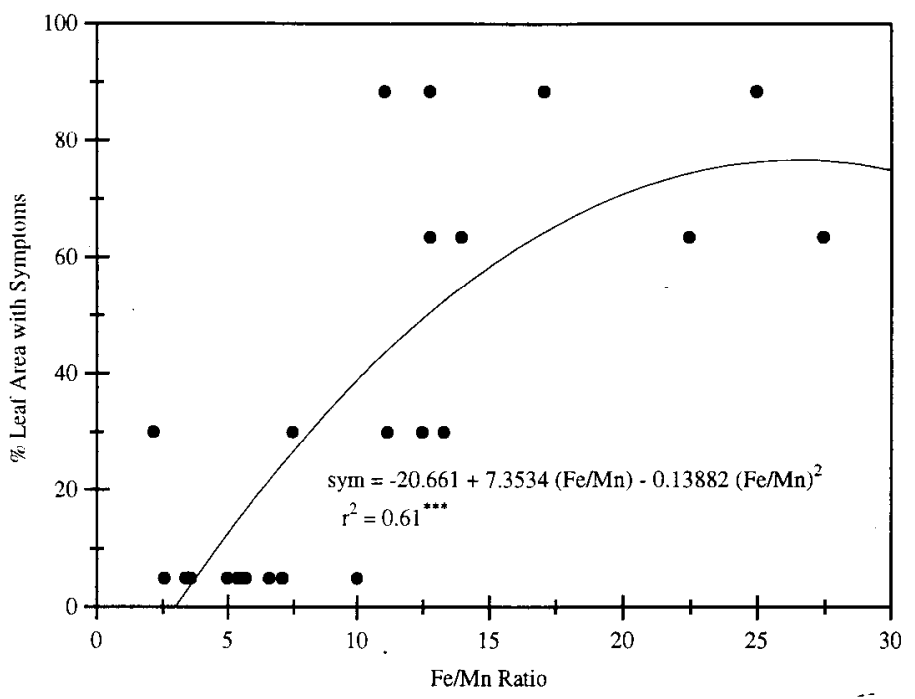

Fig. 1. Percentage of leaf area in $C$. revoluta that exhibited chlorotic/necrotic symptoms in relation to increased Fe : Mn ratio in the soil. ${ }^{* * *}$ Significant at $P=0.001$. soil analysis revealed little correlation $\left(r^{2}\right.$ $<0.28$ ) with soil nutrient levels or $\mathrm{pH}$ with percent symptoms. Iron : manganese ratios in the soil ranged from 0.19 to 2.4, although 20 of the plants had soil Fe: Mn ratios< 1.5. The soil $\mathrm{pH}$ ranged from 6.3 to 8.0 (average $=7.13$ to 7.66), with symptom seventy associated with higher $\mathrm{pH}$ values. Nevertheless, it appears from these results that $\mathrm{Mn}$, although weakly correlated to symptom severity, has a higher correlation $\left(r^{2}=0.49\right)$ with the problems noted than any of the other nutrients. The soil Fe: Mn ratio had a relatively high correlation $\left(r^{2}=\right.$ 0.61 ) with the percentage of leaf surface area that exhibited chlorotic/necrotic symptoms (Fig. 1). Responses for percent visual plant symptoms to increased $\mathrm{Fe}: \mathrm{Mn}$ ratios in the soil were consistent with other data, i.e., $82 \%$ of the samples with $\mathrm{Fe}$ : $\mathrm{Mn}$ ratios of $\leq 10$ were symptom-free.

Although subjective, the visual rating systern used in the survey was adequate for obser-

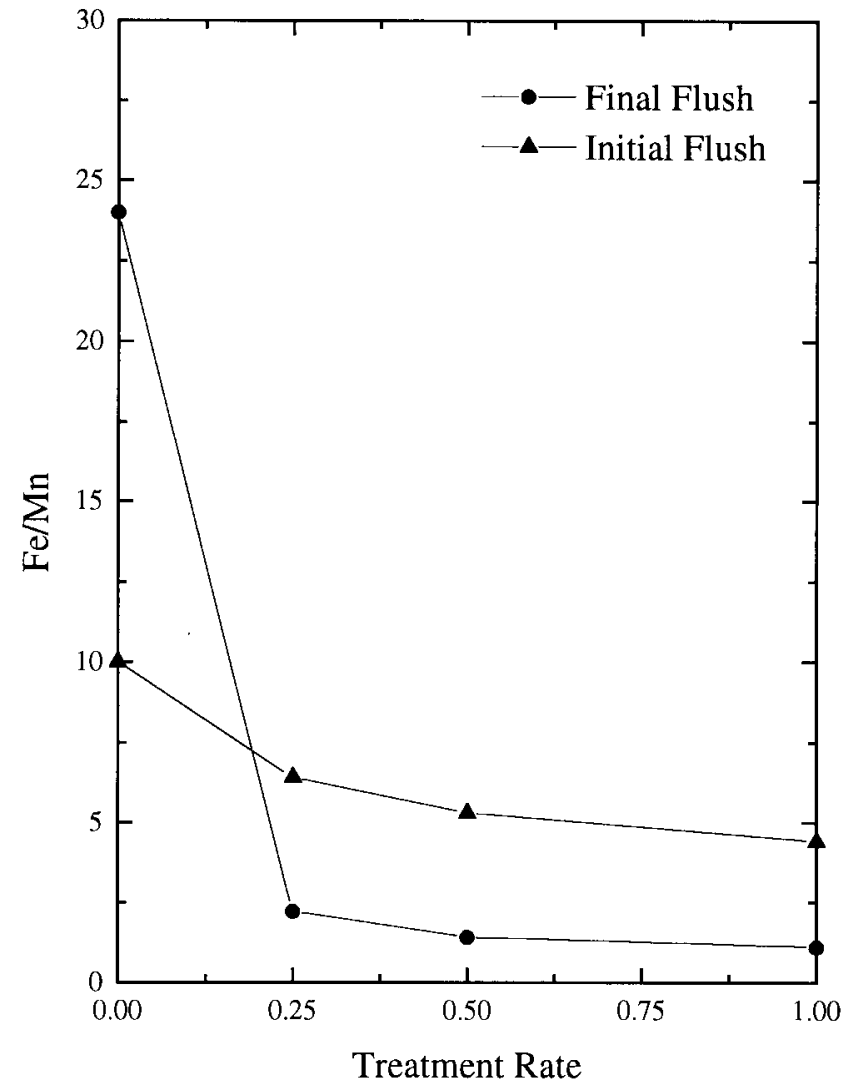

ig. 2. Mean Fe and Mn levels (ppm) in C. revoluta leaflets tissue from plants treated with Hoagland solution with various $\mathrm{Mn}$ concentrations $(0,0.25,0.5$, and $1.0 \mathrm{ppm})$. Note that $\mathrm{Fe}: \mathrm{Mn}$ ratios decline with minimal treatment, and symptoms do not appear even with low $\mathrm{Fe}: \mathrm{Mn}$ ratios. Symptoms appear at $\mathrm{Fe}: \mathrm{Mn}$ ratios $\geq 10(\mathrm{n}=36)$ 
vations of trends. The plants of Cycas spp. are usually grown from seed and may have varying phenotypic reactions to Mn deficiency. As noted by Jones ( 1972), very small differences in Mn can result in different reactions in plants.

The mean Mn level for seemingly healthy tissue was 10.4 ppm in the dry matter. Dickey (1977) has noted that many Florida soils, particularly acidic sandy ones low in organic matter and cation exchange capacity, are relatively low in Mn. Espinosa et al. (1991) considered $40 \mathrm{ppm} \mathrm{Mn}$ in forage to be below the critical value and suggestive of deficiency in central Florida soils. Other studies have found that deficient cycads averaged $18 \mathrm{ppm} \mathrm{Mn}$, whereas symptom-free plants averaged $\approx 29$ ppm (Jones et al., 1991).

Manganese effect. The Spring 1986 growth flush was the first produced under experimental conditions. This flush did not exhibit any visible signs of Mn deficiency in any of the treatments. Plants did produce sporadic growth during Summer 1986. During this period some plants of the $0 \mathrm{ppm} \mathrm{Mn}$ treatment exhibited symptoms associated with Mn deficiency. The symptoms were chlorotic spots on the margins of leaflets. In some cases, the spots coalesced and developed necrotic centers. However, with the Spring 1987 growth flush, all nine replications of the $0 \mathrm{ppm} \mathrm{Mn}$ treatment were affected. The symptoms appeared on the new growth and progressed in the same manner as previously described. None of the replications in theothertreatmentsexhibited deficiency symptoms. No symptoms were apparent even at the lowest $(0.25 \mathrm{ppm}) \mathrm{Mn}$ concentration in the treatment solution. However, the $\mathrm{Fe}: \mathrm{Mn}$ ratios where symptoms appear (<10) (Fig. 2) are consistent with earlier observations (cf. Fig. 1). This seems to indicate a very narrow range between adequate and inadequate $\mathrm{Mn}$ levels. It also supports the belief that, as a putative calcicole (Walker, 1976), C. revoluta has an inherently low Mn requirement. Such plants, as defined by Simpson (1938), occur on calcareous soils but are rare or absent on acid soils. A similar situation has been shown by Hewett (1964) for the cycad Zamia floridana A. DC., the only United States indigenous cycad. However, analogous to differential Mn absorption by menocotyledons and dicotyledons, gymnosperms also may vary in their ability to absorb Mn. Kowalenco (1989) noted that growth of corn(Zea mays L.) and oat (Avena sativa L.) in minus-Mn sand culture was drastically reduced in 43 days, whereas cauliflower and broccoli (Brassica oleracea L., Botrytis Group) continued normal growth for 90 days.

Prophylaxis. This final experiment provided conclusive evidence that Mn deficiency is the most likely cause of the observed disorder. In contrast to abundant necrosis on the nontreated plants (Fig. 3 B and C), all five replications treated with Mn exhibited a notable decrease in symptoms on the treated growth flush and appeared healthy (Fig. 3A), thus reflecting the higher Mn concentrations in the treated plants (Table 1). Although only the current growth flush is affected by the treatment and symptoms reappear the follow-

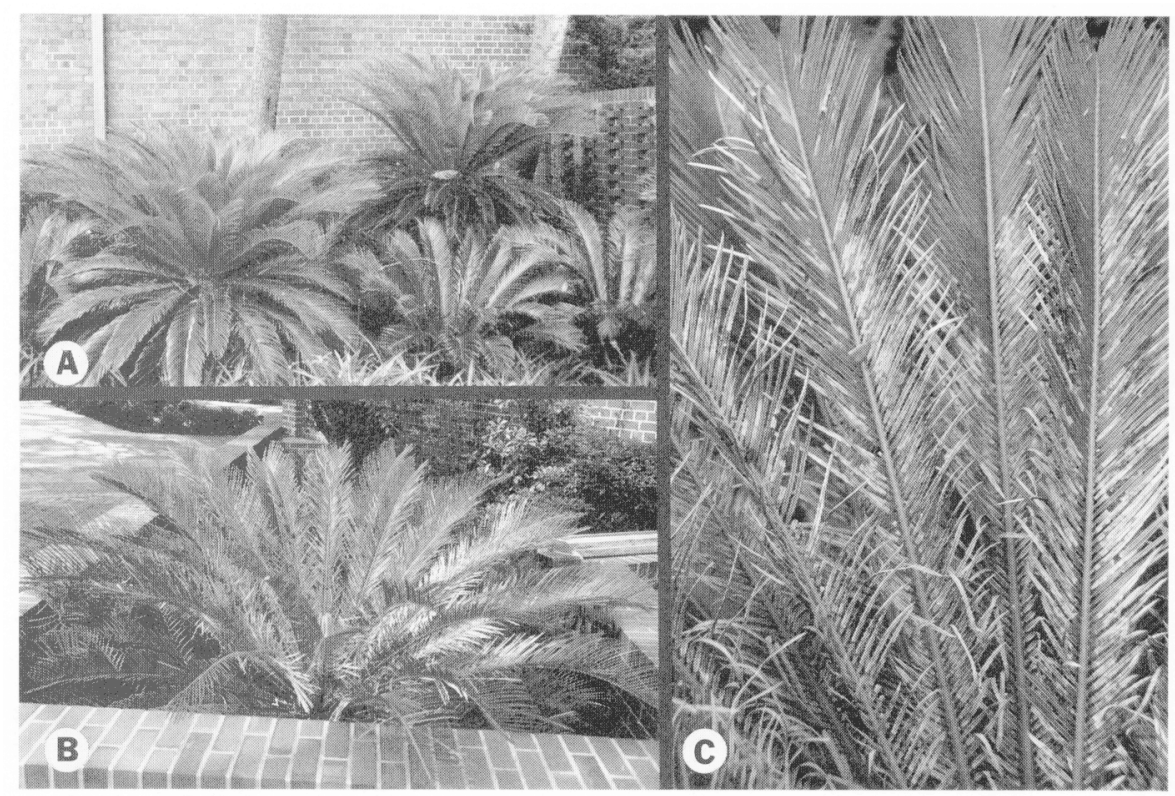

Fig. 3. Cycas revoluta in landscape situations in Gainesville, Fla. (A) Healthy plants with no Mn deficiency symptoms. (B) A plant exhibiting typical Mn deficiency. (C) Closeup of leaves exhibiting chlorotic/ necrotic symptoms.

ing year, these results suggest a practical method of correcting Mn deficiency of C. revoluta in the landscape. As with other foliar micronutrient sprays, benefit is realized only on the treated growth flush. Because of the slow growth rate of sago palm, typically with only one growth flush per year, a single annual treatment should suffice. Similar application rates have been reported for $\mathrm{MnSO}_{4}$ applications on wheat (Triticum aestivum L.) grown in Mn-deficient soils (Sadana et al., 1991). Broschat (1991a) has indicated that soil application of $\mathrm{MnSO}_{4}$ is known to be more effective and last longer on Pygmy date palm (Phoenix robelinii O'Brien) than foliar sprays and works on Cycas as well, when applied annually (personal communication).

\section{Conclusions}

Although a cause-and-effect relationship is shown between Mn deficiency and/or Mn: $\mathrm{Fe}$ ratio and development of symptoms in C. revoluta, certain cultural observations should be noted. For example, in many landscape situations the development of symptoms may be the result of a poor root system, not low Mn availability in the soil. Root growth and regeneration is usually very poor when extremely pot-bound $C$. revoluta are planted in the landscape. Because $C$. revoluta is usually grown from seed, there is also the possibility of

genotypic variation in expression of deficiency symptoms, as has been reported in other taxa (Borys, 1990; Raja et al., 1989). Thus, root pruning (cf. Dehgan and Johnson, 1987) and proper transplanting techniques should be investigated as possible means of preventing Mn deficiency.

The characteristic traits of Mn deficiency may be attributed to the physiologically immobile nature of Mn. However, it is noteworthy that over- or undeirrigation may in some cases cause Mn deficiency (Adams, 1990). Most cases of reported Mn deficiency in Cycas are the result of plants grown near lawn sprinklers or sidewalks and roadways, where they receive little or no irrigation. In both cases, the symptoms initiate as necrotic spots and/or tip dieback of leaflets of the leaf apex. Depending on the severity of the water excess or deficit, the necrosis gradually or quickly spreads to the leaf base. This pattern is in contrast to $\mathrm{Mn}$ deficiency in $C$. revoluta, which begins in the middle leaflets of expanding leaves and moves rapidly in both directions. Certain mulches have also been reported to cause foliar $\mathrm{Mn}$ deficiency, suggesting detrimental effect on Mn uptake (Jobidon et al., 1989). Broschat (1991b) has reported binding of 70\% of Mn added to sewage sludge compost media and $\leq 62 \%$ for pine bark, sedge peat, and sand medium, within $1 \mathrm{~h}$. Irrespective of the cause and the symptoms, plants removed from the

Table 1. Mean $\mathrm{Mn}$ and Fe levels $(\mathrm{ppm})$ in leaf tissue of growth flushes of $C$. revoluta $(\mathrm{n}=5)$ not treated or treated with Mn-chelate.

\begin{tabular}{|c|c|c|c|c|c|c|}
\hline \multirow[b]{3}{*}{ Flush } & \multicolumn{6}{|c|}{ Plants } \\
\hline & \multicolumn{3}{|c|}{ Controls } & \multicolumn{3}{|c|}{ Treated } \\
\hline & $\mathrm{Fe}$ & $\mathrm{Mn}$ & $\mathrm{Fe}: \mathrm{Mn}$ & $\mathrm{Fe}$ & $\mathrm{Mn}$ & $\mathrm{Fe}: \mathrm{Mn}$ \\
\hline & & & ppm & & & \\
\hline Previous & 76 & 4.5 & 17.0 & 114 & 10.5 & 10.9 \\
\hline Most recent & 51 & 3.5 & 14.7 & 52 & 25.0 & $2.1^{z}$ \\
\hline
\end{tabular}

${ }^{\mathrm{z}}$ All plants devoid of chlorotic/necrotic spots. 
landscape and planted in containers, with proper care, usually recover in the following growing season. In certain forest tree crops, such as Pinus radiata D. Don., Mn treatment in the nursery is recommended for plants to be established in Mn-deficient areas (Ronde et al., 1988). Considering the well-known susceptibility of cycads to micronutrient deficiencies, it is highly recommended that all plants be supplied with a complete micronutrient fertilizer during growth in containers and prior to field planting.

\section{Literature Cited}

Adams, P, 1990. Effect of watering on the yield, quality and composition of tomatoes grown in bags of peat. J. Hort. Sci. 65:667-674.

Agarwala, S.C., B.D. Natyal, C. Chatterjee, and C.P. Sharma. 1988. Manganese, zinc and boron deficiency in mango. Scientia Hort. 35:99107.

Borys, M.W. 1990, Deficiency of Fe, Mn, Zn, in commercial orchards of Crataegus pubescens (H.B.K.) Stend-Summary of observations. Acta Hort. 274:71-78.

Broschat, T.K. 1991a. Effect of manganese source on manganese uptake by pygmy date palm. HortScience 26: 1389-1391.

Broschat, T.K. 1991b. Manganese binding by municipal waste composts used as potting media. J. Environ. Hort. 9:97-100.

Bussler, W. 1958. Manganese deficiency symptoms in higher plants. Z. Pflanzenernäbr. Dung. Bodenk. 81:225-241.

Dehgan, B. and C.R. Johnson. 1987. Root branching in Zamia floridana: Effect of growth regulators and anatomical features. HortScience 112:10411044.

Dickey, R.D. 1977. Nutritional deficiencies of woody ornamental plants in Florida landscapes. Agr. Expt. Sta., Inst. Food \& Agr. Sci., Univ. of Florida, Gainesville. Bul. 791:1-63.

Donohue, S.J. (cd,). 1983. Reference soil test methods for the southern region of the United States. Southern Coop. Ser. Bul., U.S. Dept. Agr. Publ. 289, Raleigh, N.C.

Espinosa, J.E., L.R. McDowell, N.S. Wilkinson, J.H. Conrad, and F.G. Martin. 1991. Monthly variation of forage and soil minerals in central Florida IL Trace minerals, Commun. Soil Sci. Plant Anal. 22:1137-1149.

Hewett, D.E. 1964. Some factors affecting the distribution of Zawia in Florida. MS Thesis, Dept. of Botany, Univ. of Florida.

Hoagland, D.R. and D.I. Arnon. 1950. The water-culture method for growing plants without soil. Calif. Agr. Expt. Sta. Publ. 347.

Hope Simpson, J.F. 1938, A chalk flora of the lower Greenland; Its use in interpreting the calcicole habit. J. Ecol. 26:218.

Jobidan, R., J.R. Thibault, and J.A. Fortin. The effect of straw residues on black spruce seedling growth and mineral nutrition, under greenhouse conditions. Can. J. For. Res. 19: 1291-1293.

Johansen, D.A. 1940. Plant microtechnique. McGraw-Hill Book Co., New York.

Jones, J, B., Jr. 1972. Plant tissue analysis for micro- nutrients, p. 3 19-346. In: J.J. Mortveld, P.M. Giordano, and W.L. Lindsay (eds.). Micronutrients in agriculture, Soil Sci. Soc. Amer., Madison, Wis.

Jones, J.B., B. Wolf, and H.A. Mills (eds.), 1991, Plant analysis handbook. Macro-Micro Publ., Athens, Ga.

Kowalenco, C.G. 1989. Differential response of oats, sweet corn, cauliflower and broccoli to low manganese in sand culture system. J. Plant Nutr. 12:1321-1334.

Raja, M.E., S.S. Negi, and T.M. Rae. 1989. Screening of chrysanthemum cultivars and selections for resistance to iron deficiency chlorosis. Indian J. Hort. 46:526-529.

Ronde, C. de, B.D. James, N.T. Baylis, and P.W. Lang. 1988. The response of Pitrus radiata to manganese applications at the Ruitersbos State Forest. So. Afr. For. J. 146:26-33.

Sadana, U.S., V.K. Nayyar, and P.N. Takkar. 1991. Response of wheat grown on manganese- deficient soil to methods and rates of manganese sulphate application. Fert. News 36:55-57.

Somers, I.I. and J.W. Shive. 1942. The iron-manganese relation in plant metabolism. Plant Physiol. 17:582-602.

Walker, E.H. 1976, Flora of Okinawa and the southern Ryukyu Island, Smithsonian Inst. Press, Washington; D.C, p. 125-126.

Weber, G.F. 1944. The blight disease of Cycas revoluta. Fla. Acad. Sci. Proc. 7:129-132.

Weiland, R.T., R.D. Noble, and R.E, Crang. 1975. Photosynthetic and chloroplast ultrastructural consequences of manganese deficiency in soybean. Amer. J. Bot. 62:501-508. 